\title{
Injuriesagen mod Grundtvig 1825-1826
}

\section{Indledning}

Nærværende artikel er resultatet af en undersøgelse jeg har foretaget, af den injuriesag H.N. Clausen i 1825-1826 førte - og vandt $-\bmod$ N.F.S. Grundtvig. Den umiddelbare årsag til sagsanlæget var, at Grundtvig i sit skrift "Kirkens Gienmæle mod Professor Theologiæ Dr. H.N. Clausen" rettede et meget alvorligt angreb på Clausens netop udkomne bog "Katolicismens og Protestantismens Kirkeforfatning; Ritus og Lære», og på Clausens lære som sådan; Grundtvig hævder at Clausen enten må gøre "den Christelige Kirke høitidelig Afbigt for sin uchristelige og forargelige Lærdom, eller nedlægge sit Embede og aflægge sit christne Navn". Vil Clausen ingen af delene, så erklærer Grundtvig ham "paa den eneste ægte Historisk-Christelige Kirkes Vegne for en falsk Lærer, som misbruger sit christelige Navn til at forvirre og forføre Menigheden, og som stræber at undergrave den Kirke, han giver sig ud for at ville tjene og befæste ". ${ }^{1}$

Jeg vil ikke her komme nærmere ind på de omtalte skrifter af Clausen og Grundtvig, men jeg forudsætter "Kirkens Gienmæle " bekendt. Ligeledes vil det føre for vidt at redegøre for den kirkelige debat mellem rationalisterne og de "Gammeldagstroende", der er baggrunden for "Kirkens Gienmæle" og den "mageløse opdagelse«; sidstnævnte ligger til grund for "Gienmælet «. For mig at se var der ikke tale om én opdagelse, men om en lang og indviklet erkendelsesproces, der ikke er afsluttet med "Kirkens Gienmæle». Denne erkendelsesproces er selvfølgelig Grundtvigs egen, men han er givetvis blevet inspireret af de tyske teologer Marheinicke og Neander. ${ }^{2}$ Men også dette vil det føre for vidt at udrede i detailler her; jeg vil koncentrere mig om injuriesagen og de umiddelbart dertil forbundne hændelser, hvis kronologi jeg har kortlagt som følger:

juli 1825 Den "mageløse opdagelse».

21/8 1825 Grundtvig modtager som subskribent Clausens bog. 
26/8 1825 Datoen for fortalen til „Kirkens Gienmæle», (Irenæi dag).

3/9 1825 (lørdag) Clausens bog averteres til salg.

5/9 1825 (mandag) "Kirkens Gienmæle» averteres til salg.

10/9 1825 Clausens notits i Adresseavisen ang. injuriesøgsmål.

11/9 1825 Clausens studenter mødes på Ehlers Kollegium og udfærdiger en tillidsadresse til Clausen og en hånsadresse til Grundtvig.

12/9 1825 Grundtvig svarer Clausen i Adresseavisen at Danske Lov må frikende ham.

13/9 1825 2. oplag af "Kirkens Gienmæle" udkommer.

16/9 1825 Clausen indstævner Grundtvig, og de 88 Clausenianere ytrer sig i "Dagen".

17/9 1825 De 88 Clausenianere ytrer sig i "Skilderiet ".

19/9 1825 Clausen takker Clausenianerne for støtte i sagen.

20/9 1825 Grundtvig svarer Clausenianerne i "Skilderiet».

3/10 1825 Grundtvig opsøges af stævningsmænd.

7/10 1825 Grundtvig klager til kongen over sagsanlæget.

8/10 1825 Münter sender Grundtvigs klage til kancelliet.

10/10 1825 Sagens første retsmøde, anklagen bekendtgøres.

15/10 1825 Kancelliet henviser Grundtvigs klage til domstolen, sagen kan ikke stoppes administrativt.

16/10 1825 Mynster reagerer på "Kirkens Gienmæle».

19/10 1825 3. oplag af "Kirkens Gienmæle" udkommer.

22/10 1825 Mynsters prædiken af d. 16/10 averteres til salg.

23/10 1825 Grundtvig svarer Mynster ved at prædike til kamp.

dec. 1825 Molbechs Rimkrønike udkommer.

10/3 1826 Kongelig resolution ang. salmevalget ved 1000årsfesten.

10/4 1826 Rettens kendelse afsiges.

26/4 1826 Bispernies hyrdebrev i anledning af 1000-årsfesten udsendes.

28/4 1826 Grundtvigs højtidssalmer averteres til salg, Lises mor dør.

30/4 1826 H.G. Clausen skriver til Grundtvig ang. højtidssalmerne.

1/5 1826 Grundtvig svarer H.G. Clausen, og Grundtvig trues med endnu en injuriesag. 
2/5 1826 Salmesagen sendes videre til biskop Münter.

5/5 1826 Münter sender salmesagen videre til kancelliet.

6/5 1826 Kancelliet udsteder "videre fornødne Bekendtgørelse" ang. salmevalg til 1000-årsfesten.

7/5 1826 Grundtvig prædiker for sidste gang i Vor Frelsers Kirke og han skriver udkast til afskedsansøgning.

8/5 1826 Grundtvig i audiens hos kongen, Grundtvig skriver sin afskedsansøgning og sender den til Treschow.

9/5 1826 Treschow returnerer afskedsansøgningen til Grundtvig.

10/5 1826 Grundtvig sender sin afskedsansøgning til kongen og afleverer selv et eksemplar heraf til Münter, der straks sender den til kancelliet.

$14 / 5 \quad 1826 \quad 1000$-årsfesten fejres.

23/5 1826 Kongen bevilger Grundtvig afsked i nåde.

26/5 1826 Kancelliet giver Münter besked om, at Grundtvig er løst fra sit embede.

13/6 1826 Grundtvig sender erklæring til Clausen.

16/6 1826 Clausen sender erklæring til Grundtvig.

3/7 1826 Treschow fremlægger Grundtvigs indlæg for retten.

aug. 1826 Ørsteds artikel ang. kirkeforfatningen udkommer, Clausens indlæg fremlægges i retten og Grundtvig skriver "Vigtige Spørgsmål ... " og brev til kongen.

6/9 1826 Grundtvig svarer Treschow ang. Clausens retsindlæg.

11/9 1826 Treschow fremlægger Grundtvigs skrift „Vigtige Sp. " og brev for retten.

21/9 1826 Ørsted får en kongelig irettesættelse.

28/10 1826 Votering i sagen.

30/10 1826 Domsafsigelse. 


\section{Injuriesagen: En kronologisk fremstilling af} Grundtvigs liv, debatten omkr. Gienmælet og selve sagsforløbet i perioden fra Gienmælet udkommer d. 5/9-1825 til domsafsigelsen d. $30 / 10-1826$

\section{I}

"Kirkens Gienmæle» var fra Grundtvigs side ment som et indlæg i kampen mod rationalisterne, men det var sandelig ikke noget tilfældigt indlæg, for det indeholdt efter Grundtvigs mening det fældende argument mod rationalisterne. Grundtvig ventede, at skriftet ville afføde en indgående og seriøs kirkelig og juridisk debat af følgende punkter: 1) Hvad der var sand kristendom og hvad der var falsk kristendom, 2) hvorledes den sande kristendom forholdt sig til statskirkeforfatningen og de kirkelige symboler, 3) om prof. Clausens lære, som den var fremstillet $i$ hans bog, stemte overens med den sande kristendom og statskirkeforfatningen, og 4) endelig en grundig debat af embedsedens indhold og udstrækning. Debatten og røret omkr. "Gienmælet " var da også nærmest kaotisk, men det hele udspandt sig noget anderledes, end Grundtvig havde ventet og håbet. ${ }^{1}$ I løbet af halvanden måned udkom der ikke mindre end tre oplag af "Gienmælet «; det skal dog for god ordens skyld bemærkes, at hvert af oplagene var på 500 eksemplarer. ${ }^{2}$ Reaktionerne på "Gienmælet " var i den første tid præget af forbavselse og forargelse; Mynster skriver følgende herom i sine erindringer: "Næppe har noget Skrift i Danmark frembragt en saadan Sensation som det famøse "Kirkens Gienmæle". Det var tilstede i enhver Samtale; det trængte op i Paladserne og ned i Kjældrene; og medens de Forstandige og bedre harmedes over denne Adfærd, ledtes de Uvidende i forskjellige Stænder til at anse Clausen som en Himmelstormer. ${ }^{3}$

Clausen reagerede ikke på skriftet på anden måde end, at han d. 10/9-1825 indrykkede en notits i "Adresseavisen", i hvilken han meddelte, at han "med hensyn til de $\mathrm{i}$ "Kirkens Gienmæle" fremførte injurierende Beskyldninger allerede havde giort det 
fornødne Skridt for, i overensstemmelse med sin Embedsed at forfølge Sagen på Rettens Vej. " Grundtvig svarede ganske kort d. 12/9 i næste nummer af samme blad, at det ikke drejede sig om et personligt opgør, men det var et rent kirkeligt anliggende, samt at han desuden var af den overbevisning, at Danske Lov måtte frikende ham, hvis det skulle komme så vidt som til en retssag. ${ }^{4}$ Men Clausen afviste den kirkelige stævning Grundtvig havde rettet imod ham og stævnede istedet Grundtvig for den verdslige domstol som injuriant.

De første, der offentligt gav deres stillingtagen i sagen tilkende, var nogle af Clausens teologiske studenter og kandidater. De samledes d. 11/9-1825 på Ehlers kollegium, hvor den teologiske student C.H. Visbye oplæste en tillidsadresse til Clausen og en hånsadresse til Grundtvig, som blev underskrevet af 88 studenter og kandidater. Disse adresser blev sendt til Clausen og desuden offentliggjort i "Dagen" d. 16/9 og i "Nyeste Skilderier af Kjøbenhavn « d. 17/9. Studenternes møde var oprindelig planlagt til at foregå i regenskirken, men da der gik rygter om, at nogle af studenterne ville slå Grundtvigs ruder ind, blev regensprovst Nyerup pålagt af det teologiske fakultet ikke at give dem adgang til kirken. ${ }^{5}$ Grundtvig svarer studenterne med et indlæg i "Skilderiet" d. 20/9 under overskriften "Til de 88 Clausenianere", som han indleder på følgende måde: "At I rose den I elsker, er naturligt, og det maa ei forundre mig, at Eders Kiærlighed er blind; men kommer ihu, at om I end var otte og fiirsindstyve Millioner, saa mægtede dog Eders sammenlagte Stemme ei det mindste mod Sandhedens enlige, og kunde aldrig gøre det til Christeligt, som strider imod Christendommen, og derom, det maa selv Blinde kunde føle, derom er Talen, det er Knuden, som her skulde løses! « ${ }^{6}$ Grundtvig fortsætter indlæget med at fremhæve nogle af hovedpunkterne fra "Gienmælet ".

Debatten er nu livligt i gang, omend den ikke helt har den karakter, som Grundtvig havde ønsket; men han kan nok i udstrakt grad takke sin egen polemiske facon for resultatet. Det myldrer med avisartikler og flyveskrifter. Debatten føres dog fortrinsvis i bladene "Dagen", "Skilderiet", "Telegraphen" og "Nyt theologisk Bibliotek ". I begyndelsen er disse indlæg overvejende pro Clausen, mens det siden hen bliver mere ligeligt fordelt. Som eksempler på indlægene pro Clausen kan nævnes 
følgende: Cand. theol. C.F. West: "Nogle af Pastor Grundtvigs Vildfarelser $i$ hans Angreb på Professor Clausens Skrift om Catholicismen og Protestantismen", G.L. Baden: "Om Striden imellem Professor Clausen og Pastor Grundtvig ", Kandidat Schultz: "Samvittighedsspørgsmaal til Pastor Grundtvig", U.F. Nielsen (vistnok et pseudonym): "Udfaldet af Sagen Dr. og Prof. H.N. Clausen contra Pastor N.F.S. Grundtvig for Retfærdighedens, Sandhedens og Oplysningens Domstol“, samt følgende to smædeskrifter af ukendte forfattere: "Velment Straffeprædiken og Venlig Advarsel til alle Vantroende" og "Hr. Pastor Nic. Samson Glaubenfressers kuriøse Levneds-Historier på Rim ". Generelt for disse indlæg er, at de er af en meget let karakter. Indlægene pro Grundtvig formår i starten ikke at hæve sig meget over dette niveau. Som eksempler på indlæg pro Grundtvig kan nævnes følgende: C.T. Hetting: "Kirkens Sejr", J.C. Lindberg: "Bemærkninger i anledning af Kirkens Gienmæle", P.A. Fenger: "Oplysninger til Kandidat West angaaende Grundtvigs saakaldte Vildfarelser ". ${ }^{7}$ Disse skrifter og den almindelige forargelse til trods må man nok sige, at Clausen stod mere isoleret end Grundtvig i denne sag; Grundtvig havde dog et tidsskrift og nogle entusiastiske tilhængere, der talte hans sag og bakkede ham op. Clausen skriver bittert følgende i sine erindringer om sine kolleger: "De teol. Kolleger syntes ligesom Tilskuerne paa den sikre Strandbred med Havsnøden for $\varnothing_{j e}$ kun betænkte paa at holde sig uden for Brændingen ${ }^{8}$. Clausen selv forholder sig tavs, hvilket han forklarer på følgende måde: "... jeg tav, fordi jeg ikke kunde overvinde mig til at tale, hvor de første Betingelser fattedes for en værdig Strid i Sandheds Tjeneste; giensidig Tillid til hinandens Retsindighed, og udvordes Velanstændighed. Jeg tav fordi jeg ansaa det for unyttigt at tale, hvor Begreber om Kristendommens og Protestantismens Væsen, om Fornuftens Væen og Videnskabernes Ret ere grundforskjellige. Jeg tav endelig, fordi jeg ansaa det for overflødigt at retfærdiggøre mig for den Del af mine Medborgere, hvis Agtelse har sand Værd i mine Øjne". ${ }^{9}$

Den 3. oktober 1825 bliver Grundtvig opsøgt i sit hjem i Prinsensgade $310^{10}$ af to stævningsmænd, der meddeler ham Hof- og Stadsrettens stæuning til at møde på råd- og domhuset d. 10/10-1825 for "at høre saggivelse og lide dom " ${ }^{11}$ Efter at 
have spekuleret herover sender Grundtvig d. 7/10 gennem biskop Münter en klage til kongen over Clausen, fordi denne har indstæunet ham "for sin Embedsførelse som Injuriant". ${ }^{12}$ Grundtvig hævder i denne klage, at han har handlet ex officio, hvorfor han anmoder kongen om, at injuriesagen må blive afvist som ulovlig. ${ }^{13}$ Grundtvig anfører følgende tre grunde til at sagen bør afvises ved retten: 1) Beskyldningerne i "Gienmælet " angår ikke Clausens almindelige eller borgerlige agtelse, da det alene drejer sig om en religiøs strid. 2) Domstolene skulle ikke være berettigede til, på privat mands forlangende, at drøfte en strid om religiøse genstande på den eneste måde, der formentlig er mulig for retten, nemlig efter landets borgerlige love, og 3) at han med "Gienmælet" alene har opfyldt fordringerne i hans embedsed. Når Grundtvig hævder, at han har handlet ex officio, grunder han det på at "alle Danske Præster forpligtes ved deres Embeds-Eed til, hvad der desuden var deres Skyldighed, ei blot selv at flye og skye, men ogsaa med al Magt at bestride den mod Guds Ord stridende Lærdom, og hellere lade Livet end give falske og fanatiske Sætninger Medhold ". ${ }^{14}$

Biskop Münter sender Grundtvigs klage videre til kancelliet d. 8/10 vedlagt en følgeskrivelse, hvori han beklager hele sagens opståen og samtidig tilføjer, at han dårligt kan opfatte Grundtvigs angreb på Clausen som hørende under hans embedspligter, som han så tørt udtrykker det: "Hans Embedspligt er at være Præst paa Christianshavn ". ${ }^{15}$ Der udfærdiges ingen kongelig resolution i anledning af denne klage, kancelliet henviser spørgsmålets afgørelse til retten, der først d. 10/4-1826 afgiver en kendelse herom, hvilket vi vender tilbage til senere. Kancelliet pålægger d. 15/10-1825 biskop Münter at meddele Grundtvig, at sagen ikke kan stoppes administrativt, men at det står ham frit for at fremføre, hvad han finder tjenligt for sit forsvar ved domstolen. $^{16}$

I mellemtiden, d.v.s. mellem klagens indsendelse og kancelliets svar til biskop Münter, finder det første retsmøde sted $\mathrm{d}$. 10/10-1825. Det skal iøvrigt bemærkes, at Clausen straks ved sagsanlæget blev bevilget fri proces, hvilket senere blev nægtet Grundtvig. Anklageren P.E. Sporon ${ }^{17}$ anførte i sit første indlæg i sagen de injurierende udtryk i følgende seks punkter: "1) Prof. Clausen har stillet sig i Spidsen for alle den kristelige Kirkes 
Fjender; 2) og for alle Guds Ords Foragtere i Landet; 3) han fornægter og nedbryder Troen paa Kristus og den Kristelige Aabenbaring; 4) han har vovet et ligefrem Angreb paa den i Danmark eksisterende kirkelige Lovgivning; 5) han maa anses uværdig til al litterær og moralsk Agtelse, og 6) han har endog været ugudelig nok til af ond Vilje at lære og handle mod sin bedre Overbeviisning. "Sporon hævder, at disse beskyldninger "maa i udmærket høj Grad anses for krænkende for Citanten med hensyn til dennes offentlige Stilling som Lærer i Teologien. "Sporon anfører ligeledes det paradoxale $i$, at Grundtvig i Gienmælets fortale bekender, at han selv først for nylig er blevet klar over, hvad der er den kristne kirkes grundvold, samtidig med at han går ud fra som givet, at alle andre straks kan gennemskue, hvor han trækker grænselinien. Sporon ved ikke "om man har mest Aarsag til at undres over eller beklage en saadan Aandelig Hovmod. "På Clausens begæring nedlægger Sporon ingen påstand om straf, men henstiller til retten om at udmåle straffen, så den står $\mathrm{i}$ passende forhold til indstæuntes brøde. Derimod nedlægger Sporon påstand om, "at de paaankede af Indstæunte ... fremførte skammelige og ærerørige Sigtelser og Beskyldninger vorde kendt døde og magtesløse at være. “ ${ }^{18}$

\section{II}

Injuriesagen har nu startet sin langsommelige gang på råd- og domhuset, og noget egentligt i sagen sker der faktisk ikke, før retten afsiger sin kendelse d. 10/4-1826. Men uden for domhuset, i den offentlige debat og i Grundtvigs liv som sådant, sker der en række begivenheder, der er vigtige til forståelsen af sagens forløb og udfald.

Grundtvig følte sig på underlig vis stærkt forbundet med Mynster; på underlig vis fordi det så afgjort ikke var gensidigt, men måske dog alligevel forståeligt $\mathrm{i}$ betragtning af dels deres familieskab (halvfætre) og dels at de i høj grad, godt nok på hver deres måde, arbejdede for det samme. Når Mynster ikke kunne mobilisere tilsvarende positive følelser over for Grundtvig, skyldes det givet, at Mynster ikke kunne tåle Grundtvigs fremfusende facon, hvilken Mynster gentagne gange havde været udsat 
for. Mynster indtog desuden i 1825 en position i København, der gjorde, at hans mening om sagen i offentlighedens øjne var interessant, så Grundtvig var meget spændt på, hvorledes Mynster ville reagere på "Gienmælet". Der hersker næppe nogen tvivl om, at Grundtvig både håbede og forventede, at Mynster ville reagere positivt, hvilket dog ikke skulle blive tilfældet. I sin prædiken i Vor Frue Kirke d. 16/10-1825 dadler Mynster, dog uden navns nævnelse, Grundtvig for med "Gienmælet" at fare frem i blinde og at gøre alt på ubelejlig måde og på upassende tid. Men Mynster tager dog heller ikke Clausens parti; han karakteriserer $\mathrm{i}$ sin prædiken Clausen som en vildfaren broder og Grundtvig som en korsets fjende. Mynster lader sin prædiken trykke under titlen "Den Christelige Visdom ", og den averteres som udkommen d. 22/10, lige tidsnok til at Grundtvig kan svare ham i sin følgende prædiken søndag d. 23/10 i Vor Frelsers Kirke. Grundtvig kalder denne svarprædiken for "Den Christelige Kamp«. Prædikenen er holdt over epistelen Efes. 6,10-17, som Grundtvig bruger til - også uden navns nævnelse - at karakterisere Mynsters holdning som lunken. Prædikenen er iøvrigt, som titlen antyder, en uforbeholden opfordring til kirkekamp og udholdenhed i denne til det sidste samt endelig en profeti om sejr. ${ }^{19}$

Umiddelbart efter denne prædiken sker der det besynderlige, at Grundtvig trækker sig helt tilbage fra krigsskuepladsen. Han forholder sig aldeles tavs fra denne prædiken og helt frem til begyndelsen af maj 1826. I denne periode skriver Grundtvig ganske vist afhandlingen "Om den Sande Christendom", men den er egentlig ikke noget polemisk indlæg i debatten, den er snarere en redegørelse og en begrundelse for hans nye syn på trosbekendelsen, der formodentlig nok så meget er skrevet, for selv helt at komme til klarhed på dette punkt.

H.J.H. Glædemark fremfører $\mathrm{i}$ en artikel "Om Grundtvigs nedlæggelse af Præsteembedet i 1826" en udmærket og overordentlig sandsynlig forklaring på, at Grundtvig i føranførte periode forholder sig tavs i debatten, som jeg her ganske kort vil referere: Der er slet ingen tvivl om, at Grundtvig selv er opildnet til kamp og fuldt og fast tror på kampens endelige sejr, da han d. 23/10 talte til sin menighed i Vor Frelsers Kirke, men ved nærmere overvejelse af situationen falder Grundtvig hen i dyb depression. Der er på det aktuelle tidspunkt gået knap to måneder 
siden "Gienmælet" udkom, og selv om debatten har været livlig nok, så var den mere præget af skandalelyst og forargelse end af en egentlig seriøs teologisk og juridisk drøftelse af de præsenterede problemer. Der var slet ingen af de prominente teologer eller jurister, der var gået ind $i$ en diskussion af hvad der var sand kristendom, og hvorledes denne forholdt sig til henholdsvis de kirkelige symboler, statskirkeforfatningen og præsteeden. Men det værste stød for Grundtvig var givetvis, at Clausen ikke indlod sig på nogen polemik men i stedet vendte hele sagen ved at reducere den til et privat borgerligt injuriesøgsmål. Grundtvigs iøvrigt meget sparsomme brevveksling i denne periode vidner også om en depressiv tilstand og et stort behov for $i$ det uendelige at vende og dreje sagen i et desperat forsøg på over for sig selv at forklare, bortforklare og akceptere tingenes tilstand, hvilket helt afgjort ikke var let. Glædemark forklarer altså Grundtvigs tavshed som et udslag af hans dårlige psykiske konstitution. ${ }^{20}$

I et brev til Ingemann dateret d. 4/11-1825 svarer Grundtvig på, at Ingemann $\mathrm{i}$ et brev af $\mathrm{d}$. 3/11 har givet udtryk for, at enkelte punkter i "Gienmælet", så som at Clausen skulle tilbagekalde, hvad han havde sagt, eller nedlægge kristennavnet, nok var at gå lidt for vidt. Grundtvig skriver således: "Grunden, hvi jeg ... dog aldrig noget Øieblik har kunnet ønske hine Udtryk anderledes, er ingenlunde den, at de efter min fuldeste Overbeviisning er i alle Henseender forsvarlige, " og videre: "Grunden er, at det er mig moralsk umuligt at udslette dem, da de faldt mig i Pennen, uagtet jeg godt saa, det var ved dem, man vilde gribe mig. Det er paa andet Dansk, hvad jeg veed, du ikke misforstaaer: Bogen har jeg paa en Maade selv skrevet, men Fortalen har Vor Herre gjort «. ${ }^{21}$ Når Grundtvig her skriver, at hans udtryk ikke $\mathrm{i}$ alle henseender er forsvarlige, må han mene, at visse udtryk i "Gienmælet " er juridisk ulovlige. Grundtvig, der d. 12/91825 i "Adresseavisen " bekendtgjorde, at Danske Lov måtte frikende ham, har altså nu den 4/11 mistet troen på at kunne vinde sagen. Af samme brev fremgår det, at Grundtvig føler sig forladt af gamle venner, "thi enten fnyse de ogsaa imod mig eller tie bomstille, eller omtale Sagen med en Kulde, der end er mere utaalelig. " 22

I denne Grundtvigs tavse periode făr han nogle vægtige forbundsfæller, der formår at hæve debatten noget over det skanda- 
le- og sensationslystne niveau, der ellers var karakteristisk for den. A.G. Rudelbach startede allerede i oktobernummeret af "Theologisk Maanedsskrift" en kritisk gennemgang af Clausens bog, der strækker sig over ikke mindre end to hele årgange af månedsskriftet. Den 12/11-1825 averterer F.W. Engelbrecht sit skrift "Dr. Morten Luthers Forsvar i Anledning af Professor Clausens Beskyldninger imod ham" til salg, og ugen efter, d. 19/11-1825 udgiver Jens Hornsyld "Nogle Yttringer om den Hellige Skrift fremsat af Dr. Prof. H.N. Clausen i Bogen "Katolicismens og Protestantismens Kirkeforfatning; Lære og Ritus ", drøftet af Jens Hornsyld «. I januar 1826 udgiver Rasmus Møller stiftsprovst i Købelev (senere biskop i Maribo) skriftet "Rationalismen, i dens Forhold til Bibelen og Protestantismen, fra et populært Standpunkt betragtet «. ${ }^{23}$

Clausen, der længe har ønsket at give sine synspunkter til kende, men ikke har villet nedlade sig til polemik med Grundtvig og hans "slæng ", ser i Rasmus Møllers skrift en kærkommen lejlighed, og han svarer i "Nyt Theologisk Bibliothek" med artiklen "Sendebrev til Hr. Stiftprovst Dr. Møller «. I denne artikel kommer Clausen også kort ind på Engelbrechts artikel. Ligeledes i "Nyt Theologisk Bibliothek " kommer både svar og gensvar. Når Clausen overhovedet svarer disse to, skyldes det naturligvis, at de ikke står i umiddelbar forbindelse med Grundtvig. ${ }^{24}$

Men disse nye forbundsfæller sætter ikke store spor i Grundtvigs sindsstemning, efter hvad man kan slutte ud fra et brev til Ingemann dateret d. 20/5-1826. Til gengald tyder alt på, at Chr. Molbechs "Den Gamle Danske Rimkrønike», der udkommer i slutningen af december 1825, opliver Grundtvig en del og tager toppen af hans depression. Herom skriver Grundtvig følgende i brevet til Ingemann: "Herren styrkede mig, saa jeg forrettede mit Embede med Liv og Kraft, maaske bedre end nogen Sinde; men det fraregnet, var jeg de sidste tre Maaneder af forrige Aar som den, der ligger i Graven, og fik af mine saakaldte Venner sædvanlig kun den dræbende Trøst, at ogsaa i deres Øjne havde jeg begaaet en ubesindig, ukjærlig Handling, " og videre, men "Hans Engel tilsmilede mig paa hvert Blad af Rimkrøniken, saa den blev Figenbladet, der lagdes paa min Hjærtebyld og lægte den. ${ }^{25}$ Af lutter taknemmelighed skriver Grundtvig digtet "Broder Niels fra Soer", som han dedicerer til Molbech og of- 
fentliggør i "Nyt Aftenblad" d. 28/1-1825 sammen med en takkeskrivelse. Alt dette bevirker, at venskabet med Molbech genoptages, og at Grundtvig atter kaster sig over historiestudierne med fornyet inspiration.

\section{III}

Den bedring i Grundtvigs sindstilstand, der er forårsaget af Molbechs Rimkrønike, skal dog snart ødelægges igen; i de følgende måneder hænder der en hel række af begivenheder, der er medvirkende til, at Grundtvig atter falder hen i dyb depression, at han nedlægger sit embede, og at hans argumentation i injuriesagen ændrer karakter fra at have været en kamp for "den gammeldags og sande kristendom" til at blive en kamp imod censuren og hans borgerlige æres tilintetgørelse.

Den 10/4-1826 afsiger Den Kgl. Landsover- samt Hof- og Stadsret sin kendelse, der, efter en behandling af hver af de tre grunde, på hvilke Grundtvig kræver sagen afvist, slutter med følgende: "Thi Eragtes. Den af Indstævnte, residerende Cappelan ved Vor Frelsers Kirke paa Christianshavn, Hr. Nicolai Fredrik Severin Grundtvig, nedlagte Paastand om nærværende Sags Afvisning, kan ikke gives Medhold. " ${ }^{26}$ Ifølge den behandling retten havde underlagt Grundtvigs tre hovedargumenter, kunne der ikke længere herske tvivl om, at retten anså Grundtvigs udtryk i "Gienmælet" for injurierende. Samtidig afviste retten at tage stilling til hvorvidt de anførte beskyldninger var sande eller ej; retten ville altså ikke gå ind på en religiøs diskussion, men ville alene behandle sagen som en privat injuriesag. Dette var afgjort et stort nederlag for Grundtvig, og truslen om at blive dømt og dermed underlagt censur blev pludselig uhyggelig reel. ${ }^{27}$

Modgangen fortsatte; den 26/4-1826 udsendte landets biskopper et hyrdebrev til alle landets præster $i$ anledning af kirkens forestående tusindårsfest, i hvilket de, dog uden navns nævnelse, kritiserede Grundtvig for hans angreb på Clausen i "Gienmælet".

Den 10/3-1826 var der, ligeledes i anledning af tusindåret for 
Ansgars og dermed kristendommens komme til Danmark, udstedt en kongelig resolution, der meddelte præsterne tilladelse til selv at vælge salmer til festgudstjenesten, dog med den indskrænkning at "O, Store Gud, vi Lover Dig“ (Te Deum) skulle afsynges. Denne resolution havde Grundtvig forstået således, at man i det frie salmevalg heller ikke var bundet til den autoriserede salmebog, hvorfor Grundtvig havde forfattet højtidssalmerne "Den Signede Dag", "Tusind Aar stod Christi Kirke", "For al den Deel, som Gud har gjort " og "Oprunden er vor Pinse-Fest ". Den 28/4 indrykkede Grundtvig følgende notits i "Adresseavisen «: "Fra Pressen ere udkomne: Danske Højtids-Psalmer til Tusindaars-Festen, ved N.F.S. Grundtvig, residerende Cappelan ved Vor Frelsers Kirke. Disse Psalmer ere bestemt til at afsynges Pinse-Morgen ved Froprædiken i Vor Frelsers Kirke. « ${ }^{28}$ Dagen efter dvs. d. 30/4 modtog Grundtvig en skrivelse fra stiftsprovst H.G. Clausen (H.N. Clausens fader og Grundtvigs nærmeste foresatte), hvori stiftsprovsten bemærkede, at man ikke uden særlig tilladelse måtte lade andre salmer afsynge end dem, der fandtes $\mathrm{i}$ den anordnede salmebog. ${ }^{29}$ Grundtvig svarede omgående (1/5-1826) stiftsprovsten følgende: "... men (jeg) maa nødvendig tage mig den ærbødige Frihed at tilføje: Deels at Ritualet vist ikke følges nøiagtigere i Deres Høiærværdigheds egen Kirke, end i den hvis ringe Tjener jeg er, og deels, at jeg umuligt kan have læst Feil i den Kongelige Resolution af 10.ed. Marts d. A., som, paa den Mageløse Høitid, løser os fra Baandet til Bogen, naar vi kun ikke glemme: O, Store Gud, vi Lover dig, hvad aldrig har været min Hensigt. " ${ }^{30}$ Men stiftsprovsten var aldeles ikke enig i denne udlægning af resolutionen, og han sendte straks sagen videre til biskop Münter. Atter en gang har Grundtvig brugt en unødig grov form, der snarere hæmmer end fremmer hans ærinde. Münter, der ikke vil udsætte sig selv for et tilsvarende uforskammet svar, indberetter sagen til kancelliet d. 5/51826 uden først at have kontaktet Grundtvig. I sin følgeskrivelse til kancelliet anbefaler han, at man pålægger Grundtvig at holde sig til den autoriserede salmebog, da han finder Grundtvigs salmer usmagelige og uforståelige. ${ }^{31}$ Allerede dagen efter dvs. d. 6/5-1826 udfærdigede kancelliet "videre fornødne Bekjendtgørelse" til den Kgl. resolution af d. 10/3-1826, som blev sendt til biskop Münter, hvoraf det fremgik, at præsternes frie valg af 
salmer var at forstå således, at præsterne "dog ere bundne til de Psalmer, som findes i den Kongelige Autoriserede Psalmebog, men ikke berettigede til Brugen af Psalmer, som de enten selv have forfattet eller hentet andetsteds fra. " $" 32$

Hvornår Münter viderebringer denne meddelelse til Grundtvig er lidt uklart. Glædemark hævder, at biskoppen først sender sagen til kancelliet dagen efter den dato han har dateret følgeskrivelsen. (Følgeskrivelsen er dateret d. 5/5-1826). Hvorfra Glædemark har denne oplysning fremgår så vidt jeg kan se ingen steder, ej heller at det skulle få nogen betydning, men under alle omstændigheder er kancelliets svar til Münter dateret d. 6/5, hvilket biskoppen ifølge Glædemark modtager d. 8/5 (d. 7/5 er en søndag), hvorefter det sendes videre til stiftsprovsten. Stiftsprovstens skrivelse til Grundtvig findes hverken i Grundtvigs privatarkiv eller i stiftprovstens arkiv. Efter al sandsynlighed har Glædemark ret i, at Grundtvig først modtager beskeden om salmeforbudet ad den tjenestlige vej d. 9/5. Når Glædemark er så forhippet på at få budskabet frem til Grundtvig så sent som muligt, skyldes det, at hans hypotese går på, at det alene er audiensen hos kongen, der er det afgørende lod i vægtskålen til at Grundtvig beslutter sig for at nedlægge embedet. Jeg ved ikke, hvor stor vægt man kan tillægge disse beregninger af postgangens varighed, da jeg finder det overordentlig sandsynligt, at Grundtvig uofficielt og mundtligt kan have modtaget beskeden allerede d. 6/5 eller d. 8/5 om morgenen. Iøvrigt er det her vigtigt lige at erindre, at Grundtvig allerede i klagen til Kongen af $\mathrm{d}$. 7/10-1825 er inde på, at embedsnedlæggelse kan blive en nødvendig konsekvens af injuriesagen. Det er altså efter min mening ikke så lige til at afgøre, om salmestriden er medvirkende til embedsnedlæggelsen eller ej. ${ }^{33}$

Hvorom alting er, så prædiker Grundtvig for sidste gang i Vor Frelsers Kirke søndag d. 7/5-1826. Hvorvidt han under prædikenen er sig dette bevidst er vanskeligt at afgøre, men tanken må næsten have slået ham, for senere samme dag skriver han et udkast til en afskedsansøgning, der dog aldrig bliver sendt. I dette udkast begrunder Grundtvig sin ansøgning med, at injuriesagen ifølge rettens kendelse af $\mathrm{d}$. 10/4 ikke blev afvist. Som kort bemærket tidligere var Grundtvig allerede i klagen til Kongén af $\mathrm{d}$. 7/10-1825 inde på embedsnedlæggelse som en mulig 
konsekvens af sagen: „Var noget Lignende (sagsøgning for handlinger gjort ex officio og i henhold til embedseden) blot een Gang skedt, sandelig da maatte alle Danske Præster, som er Statens Religion varmt hengivne og ei agte deres Embeds-Eed for et tomt Mundsveir, kappes om at nedlægge deres Embeder. ${ }^{34} \mathrm{Vi}$ dere begrunder Grundtvig sin ansøgning med, at han trues med endnu en injuriesag af en religionslærer på en af de skoler, Grundtvig i sin egenskab af at være præst havde opsyn med. Grundtvig har efter alt at dømme taget sit hverv så højtideligt, at han, da pågældende religionslærer bestred den befalede lærebogs grundsætninger, følte sig forpligtet til at irettesætte denne, der øjensynlig er blevet meget fornærmet. Denne episode omtales imidlertid kun i dette udkast samt $i$ et brev til Ingemann dateret d. 1/5-1826. Da sagen ifølge retsprotokollerne aldrig blev ført, forbliver lærerens navn os ubekendt. Men Grundtvig forudser, at han, når han skal forrette sit embede med nidkærhed, ustandselig vil pådrage sig nye stævninger, der uanset udfaldet, vil forstyrre hans "præstelige og borgerlige Rolighed og udgiøre et Martyrdom ", som han erkender sig for svag til at bære. ${ }^{35}$ Grundtvig nævner i dette udkast intet om salmestriden.

Den følgende søndag, dvs. d. 14/5-1826, skulle tusindårsfesten for Ansgars komme til Danmark fejres i alle landets kirker, og Grundtvig, der i virkeligheden var ophavsmand til festlighederne, for så vidt som det var ham, der ti år tidligere gjorde opmærksom på jubilæet i en "Dannevirke" artikel, havde længe glædet sig. ${ }^{36}$ Han havde i denne anledning ikke blot forfattet de før omtalte højtidssalmer men også digtsamlingen "Kong Harald og Ansgar. Rim-Blade af Danmarks Kirke-Bog til JubelAaret. " Dette lille hæfte, der udkom i første uge af maj, indeholdt foruden digtene "Harald Klak", "Ansgar", "Rimbert" og "Kristi Kirke (til Dana)" også digtet "Dansk Jubel-Hilsen til Kong Frederik den Sjette", der hylder den dåd, kongen har gjort ved at genopbygge slotskirken på Christiansborg, der netop skulle indvies på festdagen. Da mandag var kongens audiensdag, var mandag d. $8 / 5$ sidste chance for at komme $i$ audiens inden festen. Når Grundtvig søgte audiens, var det vel først og fremmest for at overrække kongen digtene, men også for at fortælle kongen "hvorledes en kristelig Præsts Stilling nu til Dags var, og høre, hvad han dertil havde at svare. “ ${ }^{37}$ Grundtvig nærede givet- 
vis et fromt håb om, at kongen ville forbarme sig over ham og standse injuriesagen.

Der hersker ingen tvivl om at kongens mening spillede en stor rolle for Grundtvig. Frederik d. VI havde gennem mange år haft en udtalt sympati for Grundtvigs person som sådan, og han havde agtet ham højt som skribent, og det så meget at kongen siden 1818 havde ydet Grundtvig en årlig understøttelse på 600 rigsdaler til historiestudier, der blev bevilget for tre år ad gangen. Disse bevillinger fik Grundtvig indtil 1839, hvor han tiltrådte som præst ved Vartov. Grundtvig følte med rette, at det var af kongens nåde, at han var præst. Kongen havde personligt kaldet ham til Præstø i 1821 og året efter, trods kraftige protester og massiv modstand fra den højeste gejstlighed i København, flyttet ham til hovedstaden som kapellan ved Vor Frelsers Kirke.

Da nu Grundtvig under audiensen d. 8/5-1826 forstod, at kongen anså ham som injuriant, tog Grundtvig sig det meget nær, han følte ikke længere han kunne sidde i det embede, kongen knap fire år tidligere havde betroet ham. Han stod i det frygtelige dilemma, at han selv anså sit udfald mod Clausen i "Gienmælet " for en nødvendighed dels for hans egen samvittigheds skyld og dels for at opfylde de forpligtelser, han havde påtaget sig ved at aflægge embedseden. Skulle han fremover handle i overensstemmelse med sin opfattelse af embedseden, ville han ustandselig vække kongens misbilligelse, men skulle han handle i overensstemmelse med, hvad kongen anså for ret og rimeligt, da ville han ligge $\mathrm{i}$ evig åben strid med sin egen samvittighed. Vi må ikke glemme, at Grundtvig faktisk var overordentlig kongetro og pro enevoldsstyret lige til det faldt i 1848 . Om audiensen skriver Grundtvig selv følgende: "Alt føiede sig, jeg følte Mod og Besindighed til at sige, hvad jeg kunde, og han (kongen) optog det meget, endog vidunderlig venligt, men vedkiendte sig paa det Bestemteste Fjendens Synsmaade for mit Kirkeforsvar og Injuriesagen; nu var jeg intet Øieblik tvivlsom om, hvad jeg skulde giøre, kunde saa meget mindre være det, som Bandsættelsen i Bispernes Hyrdebrev, den i al sin Smaalighed gruelige Psalme-Historie, og en ny Proces, hvormed jeg trues, ... samlet mindede mig om intet Øieblik at opsætte, hvad jeg nu klarlig saa (nedlæggelse af embedet), skulde skee i Dag eller i Morgen. «" ${ }^{38}$

Grundtvig gik direkte hjem fra audiensen og skrev sin af- 
skedsansøgning. Denne ansøgning er en omredigering af koncepten fra dagen før. Som begrundelse for sin ansøgning anfører Grundtvig atter injuriesagen, rettens kendelse, truslen om yderligere stævninger samt, at han ikke ser sig istand til at opfylde sin embedsed under de aktuelle omstændigheder, samt at alt dette er mere end han med samvittigheden i behold kan bære. Han nævner heller ikke her noget om salmestriden. At Grundtvig ikke nævner samtalen med kongen samme dag er forståeligt nok, da en sådan ansøgning er et officielt stykke papir, der passerer mange hænder. ${ }^{39}$ Grundtvig udfærdiger ansøgningen i to eksemplarer og sender med det samme det ene eksemplar til F.W. Treschow, hans forsvarer $\mathrm{i}$ injuriesagen, for at høre hans mening om dette skridt og om, hvorvidt det kunne få betydning for sagens gang. Dette er så vidt jeg kan bedømme den første handling, der direkte vidner om, at Grundtvig nu ikke længere kæmper for den sande kristendom men kæmper imod censuren og en tilintetgjort borgerlig ære. Treschow returnerer ansøgningen dagen efter, altså d. 9/5-1826 vedlagt følgende skrivelse: "Aldrig har det kostet mig saa megen Overvindelse at levere noget Stykke Papir fra mig som det nærværende. Betænk dog, Kiæreste Ven! Om dette Skridt ikke kan undgaas; husk at Deres Beslutning egentlig først er fra Igaar; og tænk endelig paa den Stakkels Kone, der mindre kan taale dette Stød end Tabet af sin Moder, der blot lød Naturens Orden. ${ }^{40}$ Men Treschow formår ikke med dette brev at ændre Grundtvigs beslutning, d. 10/5-1826 sender han det ene eksemplar af afskedsansøgningen direkte til kongen, mens han samme dag personlig overbringer det andet eksemplar til biskop Münter. Når Grundtvig ikke ekspederer ansøgningen gennem sin nærmeste foresatte, stiftsprovst H.G. Clausen, skyldes det givetvis uoverensstemmelserne med denne i forbindelse med salmestriden. ${ }^{41}$

Grundtvig var, da han ankom til Münter, så bevæget, at bispen sendte bud til Gladsaxe efter Grundtvigs bror Otto, for at denne skulle berolige ham og evt. få ham fra sit forehavende. Dette må imidlertid være mislykkedes, for Münter går ind på øjeblikkeligt at løse Grundtvig fra sine forpligtelser og făr, grundet på den formelle videre ekspedition af sagen, Grundtvig til at gøre følgende tilføjelse til ansøgningen: "Hvorfor han allerunderdanigst beder, at en Anden strax i hans Sted maa vorde 
constitueret! « ${ }^{42}$ Münter sender samme dag sagen videre til kancelliet med en følgeskrivelse, hvori han beklager, at Grundtvig har bragt sig i en situation, som han ikke kan magte, men grundet på Grundtvigs dårlige psykiske konstitution anbefaler han kancelliet at efterkomme ansøgningen. ${ }^{43} \mathrm{Da}$ Grundtvig i sin afskedsansøgning ikke fordrer pension, kunne kancelliet ikke se nogen hindring for at anbefale hans afsked i nåde. Kongen sender d. 23/5-1826 besked til kancelliet via sin kabinetssekretær, om at han har besluttet at efterkomme Grundtvigs ansøgning. Den 26/5-1826 udfærdiger kancelliet en skrivelse til biskop Münter, i hvilken Grundtvig bevilges afsked i nåde.

Grundtvigs nedlæggelse af embedet vakte stor opsigt, og ingen forstod, hvad der havde bragt ham dertil. Mynster skriver følgende derom i et brev til Engelbrecht: "Det er Dem da sikkert bekendt, at det omsider, efter mange Aars ufortrødne Bestræbelser, synes at lykkes Grundtvig at blive forrykt. " Lindberg, Rudelbach, Hornsyld, Holm og Fenger blev ifølge Lindbergs erindringer dybt rystede. Ingemann strækker sig så langt i sin forståelse, at han ikke betvivler, at Grundtvig har haft meget tungtvejende grunde. Ifølge et brev til Ingemann kan man forstå, at Lise tager situationen pænt, men om der er tale om en egentlig forståelse for Grundtvigs handling vidner brevet intet om. ${ }^{44}$ Grundtvigs private korrespondance i perioden fra embedsnedlæggelsen til selve domsafsigelsen $\mathrm{d}$. 30/10-1826 bærer i det hele taget tydeligt præg af, at Grundtvig søger at forklare og retfærdiggøre sin handling over for sig selv og sine venner. Som den afgørende grund til embedsnedlæggelsen anfører han næsten alt lige fra kongens ord, til injurieprocessen, til trusselen om yderligere sagsanlæg og til salmekonflikten udover det, at han slet ikke egnede sig til det daglige hyrdeliv, men at han kun var skikket til at være prædikant, samt at kirken var besmittet med så mange "væmmelige Urenheder", at det længe havde været ham en lidelse, og at han blot greb en god lejlighed til at gøre sig fri. Nærmest sandheden kommer vi nu nok $i$ et brev til Ingemann dateret d. 20/5-1826, hvor Grundtvig efter at have overvejet frem og tilbage skriver, at han dybest set ikke ved hvorfor han søgte sin afsked: "men skiøndt du nok veed, det er alt store Ting, naar det staar klart for os, hvad vi skal giøre, saa maa vi finde os $i$, at det sidste store hvorfor er os meget dunkelt ... ${ }^{45}$ 


\section{IV}

Oven på nedlæggelsen af embedet, hvorved Grundtvig er blevet fritaget for embedsedens forpligtelser, søger han at opnå en mindelig bilæggelse af injuriesagen ved gennem Treschow d. 13/61826 at sende Clausen en erklæring, hvori han siger, at man efter hans overbevisning ikke tjener kristendommens sag ved processer. Derfor ser han gerne, at sagen afsluttes med, at han højtideligt og sandfærdigt erklærer, at det aldrig havde været hans hensigt med "Gienmælet" at krænke Clausens borgerlige ære eller at bedømme hans sindelag og hensigt. Han ville alene udtrykke sin egen overbevisning om Clausens forhold til det, der for Grundtvig er sand kristendom. ${ }^{46}$ Clausen svarer d. 16/6-1826 også med en erklæring, hvoraf det fremgår, at det for ham er ganske uden betydning at vide, hvorledes Grundtvig dømmer om ham, eller med hvilket sindelag han har skrevet "Gienmælet". Det, der for Clausen nu er det afgørende spørgsmål, er hvorvidt han i sin bog og Grundtvig i "Gienmælet" har misbrugt den videnskabelige frihed eller ej, og det spørgsmål finder Clausen kun kan afgøres ved en højere autoritet, hvorfor han på ingen måde kan gå ind på at hæve sagen ved en privat overenskomst. ${ }^{47}$

Sagen må altså fortsat gå sin gang, og d. 3/7-1826 fremlægger Treschow Grundtvigs indlæg for retten. Koncepten til dette indlæg er ifølge håndskriften ikke skrevet af Grundtvig selv, men formodentlig renskrevet af en af Treschows skrivere og underskrevet af Grundtvig. Det væsentlige i indlæget er, at Grundtvig ikke kan akceptere, at han bliver draget til ansvar for sin embedsførelse, som om han var uden kald og forpligtelse på embedseden. Grundtvig hævder nu, at retten kun kan dømme ham som injuriant, såfremt den først kan bevise, at hans anklager og beskyldninger mod Clausen i "Gienmælet" ikke stemmer overens med sandheden og virkeligheden. Desuden hævder Grundtvig, at han ved frivilligt at nedlægge sit embede selv har påtaget sig den straf, som staten måtte finde rimelig for den forbrydelse staten måtte mene, han har gjort sig skyldig i. Til slut nedlægger Grundtvig påstand om, at han selv må blive frifundet og Clausen dømt til dels at betale sagens omkostninger og dels at betale en bøde, der skal forebygge, at fjender af statens religion fremover søger ad rettens vej at hævne sig på præster, der blot opfylder 
deres embedsed. ${ }^{48}$ Det eneste egentlig nye argument, der kommer for dagen i dette retsindlæg, er at, Grundtvig forsøger at bruge embedsnedlæggelsen og den bevilgede afsked i nåde til at få standset sagen, idet han hævder allerede at have bødet tilstrækkeligt for den brøde, som Clausen og retten øjensynlig mener, han har gjort sig skyldig i. Det kommer ikke som nogen overraskelse, at Grundtvig søger at bruge den bevilgede afsked i nåde på denne måde, for vi ved jo, at han allerede inden afsendelsen af afskedsansøgningen til kongen og bispen henvendte sig til Treschow, for at høre om dette skridt kunne bruges i injuriesagen. Det kommer i virkeligheden helt naturligt, at han nu i dette sit paniske forsøg på at værge sig imod censuren fører dette argument til torvs. Treschow ledsager Grundtvigs indlæg med en kort og præciserende bemærkning om, at det alene drejer sig om, hvorvidt Clausen i sin bog har bestridt den lærdom, som ifølge loven skal følges i de danske kirker. ${ }^{49}$

I slutningen af juli 1826 tager Grundtvig og hans familie til Lynge ved Sorø, hvor de besøger vennen pastor Christen Olsen og nyder en hårdt tiltrængt sommerferie langt fra hovedstadens og injuriehelvedets bryderier. I midten af august tager Grundtvig hjem igen, hvor Treschow modtager ham med et langt indlæg $i$ sagen af Clausen (24 foliosider!). ${ }^{50}$ Clausen starter sit indlæg med en ganske kort opsummering af sagen og Grundtvigs argumenter indtil rettens kendelse, der skulle eliminere alle Grundtvigs påstande. ${ }^{51}$ Herefter opridser Clausen sagens realitet, det drejer sig om beskyldninger fremført $i$ en trykt bog rettet imod en anden trykt bog. "Naar det nu saaledes i det Følgende paaligger mig, ved at sammenholde og gjennemgaa de vedkommende Ytringer i mit og min Modstanders Skrift, at bevise, at de injurierende Beskyldninger, over hvilke jeg har besværet mig, virkelig findes udtrykt og gjentaget i de klareste og bestemteste Udtryk i Hr. Grundtvigs Skrift, og at de alene grunde sig paa en Fordrejelse af et eller andet Ord, hvorved en Mening er blevet indtvunget, som staar i den øjensynligste Modsigelse med den hele Sammenhæng og i Bogen selv finder den fuldkomneste Gjendrivelse. “52 Herefter afstikker Clausen retningslinierne for en sådan sammenholdning af de to skrifter. Selve hovedafsnittet består af fem afsnit, hvor Clausen gennemgår de seks beskyldninger, som han har indstævnet Grundtvig for, således at han $\mathrm{i}$ 
sidste afsnit behandler punkt 5 og 6 under et. Hvert af de fem afsnit slutter selvfølgelig med at konkludere, at Grundtvigs påstande og beskyldninger er falske. ${ }^{53}$ Clausen afslutter sit indlæg med et afsnit, i hvilket han påpeger, at Grundtvig tager fejl mht. at injuriesagen skulle være enestånde $i$ kirkehistorien, det eneste, der ifølge Clausen er enestående i kirkehistorisk sammenhæng, er den utilladelige modtagelse og behandling hans egen bog har fået. ${ }^{54}$ Rent faktisk tager Clausen gennem dette indlæg stilling til, hvorvidt Grundtvigs beskyldninger har hold i virkeligheden eller ej, men dels tages der ikke stilling til Grundtvigs hovedanklage, nemlig at Clausen er en falsk lærer, hvilket vil sige om Clausens lære er i strid med den danske statskirkeforfatning og bekendelsesskrifterne, og dels er det Clausen og ikke en uvildig instans, der foretager vurderingen, så man kan i nogen grad diskutere værdien af denne gennemgang af ankepunkterne.

Få dage efter Grundtvig har modtaget Clausens indlæg, returnerer han det til Treschow med et brev, hvoraf det fremgår, at han hverken er til sinds at læse indlæget eller for den sags skyld at besvare det. I samme brev udbygger han det nye argument fra retsindlæget af d. 3/7-1826 på følgende måde: Grundtvig hævder, at sagen ikke kan være rettet imod ham som person men alene imod ham som en embedsmand, der er bundet af sin embedsed, hvilket vil sige imod ham som statens mandatarius. "Under denne Forudsætning er det mig nemlig klart, at Sagen maatte bortfalde, eller Præsten dog, uden alt Hensyn paa hans Udførelse af sin befalede Strid, frikendes, naar Staten under Sagens Gang meddelte Præsten Afsked i Naade; ... da Staten ikke paa en Gang baade kan fordre og eftergive Regnskabet for een og samme Embeds-Førelse. Saa-meget var da herved vundet, at Præsten, naar han tiltales som Injuriant for sin Embeds-Førelse, dog i det mindste ved frivillig opofrelse af det Embede, Staten ikke havde fundet hidtil var i slette Hænder, under alle Omstændigheder kunne redde sin Skrivefrihed og undgaa den ligesaa upassende som krænkende juridiske Trætte med dem, han efter sin Embeds-Ed og dertil svarende Overbeviisning nødvendig maatte søge Ubehageligheder. $“{ }^{55}$ Grundtvig afslutter brevet til Treschow med at sige, at dette er alt, hvad han har at tilføje til sin allerede afgivne erklæring. Grundtvig anmoder Treschow om istedet for at besvare Clausens indlæg så at fremlægge hans netop 
udkomne skrift "Vigtige Spørgsmaal til Danmarks Lovkyndige» for retten. Treschow fremlægger såvel brevet som skriftet for retten d. 11/9-1826. ${ }^{56}$

Grundtvigs skrift "Vigtige Spørgsmaal til Danmarks Lovkyndige" er et svar på en artikel, A.S. Ørsted havde publiceret $\mathrm{i}$ "Juridisk Tidsskrift"s augustnummer under titlen "Behøver den danske Kirkeforfatning en omgribende Forandring?" Selv om Ørsted senere hævder, at han har skrevet denne artikel som et indlæg i debatten om symbolforpligtelsen og, at det aldrig havde været hans intention at afgive votum i den løbende sag mellem Grundtvig og Clausen, så er hans tolkning af kirkelovene så tydeligt i Clausens favør, at den næppe kan tolkes som andet. Så længe Ørsted ikke kan bevise at symbolforpligtelsen og diskussionen herom er injuriesagen uvedkommende, så længe er det vanskeligt ikke at opfatte hans artikel som et votum i sagen. ${ }^{57}$ Clausen undlader da heller ikke i sit før omtalte lange retsindlæg at henvise til Ørsted og hans artikel. ${ }^{58}$ Det er klart, at Grundtvig føler sig meget ilde berørt over, at Ørsted således inden domsafsigelsen gav sin mening om sagen offentligt til kende, for som Grundtvig selv skriver $i$ indledningen af "Vigtige Sp...«: "... da Hr. General-Procurøren, som beklæder et af de to vigtigste juridiske Embeder i Landet, og beklæder desuden i vor juridiske Litteratur et Høi-Sæde, der letteligen kunde giøre hans Stemme til et Orakel-Sprog, ... da han ikke har taget i Betænkning, saa tidligt og lydeligt at ytre sin afgjorte Partiskhed for min Modpart, bør jeg naturligvis endnu mindre tage i Betænkning, ligesaa lydeligt at ytre min afgjorte Partiskhed om ikke for mig selv, saa dog for den Sag jeg forsvarer; thi jeg maa jo kalde det store Ting, om Danmarks Lovkyndige vil skjænke mine Grunde saa megen Opmærksomhed, som de sikkert skjænke Hr. Etatsraad Ørsteds blotte Stemme. «" ${ }^{59}$

Året efter hævder Grundtvig i sit skrift "Om Religions-Frihed ", at det var Ørsteds votum, der fik ham dømt. ${ }^{60}$ Også Lindberg går i rette med Ørsted i skriftet "Hvad er Christendom i Danmark? Med Hensyn til Professor Paulsens, Etatsraad Ørsteds og de danske Biskoppers Ytringer om de symbolske Bøgers Myndighed og Præsteedens Betydning i Danmark. « Både i Grundtvigs og i Lindbergs skrift er drøftelsen forsøgt ført udfra rent juridiske præmisser, og begge forfattere står uforstående 
over for Ørsteds fortolknings problematik, idet de mener at symbolforpligtelsen efter dansk ret må være absolut. ${ }^{61}$ Ørsted var desuden $i$ denne sin artikel kommet for skade at kalde treenighedslæren ikke bevidnet $\mathrm{i}$ bibelen og derfor ikke omfattet af symbolforpligtelsen. Daværende justitsminister og chef for politiet J.F. Kaas, der i mange år havde været i opposition til Ørsted i kancelliet, benyttede straks lejligheden, vist nok på foranledning af Lindbergs skrift, ${ }^{62}$ til at angive Ørsted til kongen for at have fremført uortodoxe standpunkter. Kaas havde vist egentlig haft ambitioner om at få Ørsted afsat som generalprokurør, men så vidt kom det dog aldrig. Den 21/9-1826 fik Ørsted en kongelig irettesættelse, ifølge hvilken Ørsted måtte fratræde som docent i kirkeret ved pastoralseminariet og blev påbudt at indstille sit forfatterskab, alt sammen begrundet med 1: Det utilbørlige i at Ørsted havde udtalt sig offentligt og derved påvirket domstolens afgørelse, og 2: Det betænkelige i at Ørsted havde indladt sig på drøftelse af teologiske problemer. Ørsted fik dog lov til at færdiggøre påbegyndte arbejder, hvilket også betød, at han måtte afslutte sin artikel om kirkeforfatningen. I den sidste halvdel heraf koncentrerede Ørsted sig om at bevise, at der mht. kirkeforfatningen ikke var behov for ændringer. Dette var rent faktisk en imødegåelse af Clausens forslag til ændring af fx. præsteeden. Til sidst $\mathrm{i}$ artiklen bragte Ørsted et kort svar til Grundtvig og Lindberg. ${ }^{63}$

Hele denne uoverensstemmelse imellem kongen og Ørsted forsøger Grundtvig, i et sidste panisk forsøg på at værge sig mod censuren, at drage fordel af ved at sende kongen et eksemplar af "Vigtige Sp..." samt et brev, hvori Grundtvig indtrængende anmoder kongen om at læse skriftet, underforstået at kongen derigennem skulle få syn for den uretfærdighed, der var ved at overgå Grundtvig, således at kongen kunne gribe ind, og Grundtvig fortsat kunne tjene kongen og fædrelandet med sin pen. Kongen reagerede aldrig på hverken brevet eller det vedlagte skrift. ${ }^{64}$

\section{V}

Den 28/10-1826 er der votering i sagen og d. 30/10-1826 finder selve domsafsigelsen sted. Så vidt jeg har kunnet få oplyst, bør 
en voteringsprotokol indeholde såvel en rådslagning som selve voteringen samt den dom, der slutteligen voteres om. Ikke desto mindre er landsover- samt hof- og stadsrettens voteringsprotokols og domsprotokols udskrifter i sagen identiske, alene med den afvigelse, at voteringsprotokollen til slut har en bemærkning om stemmeenighed samt de fem dommeres underskrifter, ${ }^{65}$ hvilket altså vil sige, at voteringsprotokollen ikke indeholder nogen form for rådslagning. Dette kan, såvidt jeg kan se, kun forklares på følgende måde: En af de fem dommere eller retten som sådan har til d. 28/10-1826 udarbejdet indholdet af voteringsprotokollen som en slags udgangspunkt for rådslagning, men da alle fem dommere umiddelbart har kunnet tilslutte denne koncept, er den blevet skrevet lige ind i voteringsprotokollen med en bemærkning om stemmeenighed og er derpå blevet underskrevet. På denne måde har der slet ikke været nogen egentlig rådslagning eller behov for en sådan. Indholdet af voteringsprotokollen føres så to dage senere d. 30/10-1826 direkte ind i domsprotokollen.

Retsprotokollerne starter med en kort præsentation af sagens implicerede parter samt en bemærkning om, at det drejer sig om fornærmende og ærekrænkende beskyldninger, der ikke her præciseres nærmere. ${ }^{66}$ Det anføres herefter, at Grundtvig har nedlagt påstand om sagens afvisning, hvilket retten med kendelsen af $\mathrm{d}$. 10/4-1826 har afvist. Grundtvig har påny nedlagt påstand om sagens afvisning pga. den af kongen ham meddelte afsked i nåde, hvilket retten forkaster, ligesom den forkaster Grundtvigs påstand om, at den meddelte afsked i nåde skulle være frifindelsesgrund. Retten akcepterer heller ikke, at Grundtvig pga. sin embedsed skulle være forpligtet på endsige berettiget til at fremkomme med de udtalelser og beskyldninger, som han er indstævnet for. Retten vil alene betragte sagen som et rent privat injuriesøgsmål imellem Grundtvig og Clausen. Retten vil heller ikke indlade sig på nogen diskussion af rigtigheden af Grundtvigs anklager; den vil altså ikke undersøge, om Clausen rent faktisk er en falsk lærer, eller om hans bog skulle stride imod den danske kirkeforfatning. Retten vil alene diskutere, hvorvidt de udtalelser og beskyldninger, som Grundtvig er instævnet for, er at betragte som utilbørlige og fornærmelige, hvilket retten konkluderer, at de er. Selv om retten lige har afvist at anstille en 
undersøgelse af, om Clausen skulle være en falsk lærer, eller om hans bog skulle være i strid med den danske kirkeforfatning, så indlader den sig alligevel på at anføre, at Clausens lære i det væsentlige synes at stemme overens med et af kongen godkendt, og af alle landets biskopper udsendt hyrdebrev. ${ }^{67}$ Slutteligen konkluderer retten, at de påankede udtalelser kendes for "døde og magtesløse at være", og at indstævnte dømmes til at betale en bøde på 100 rigsdaler sølv til Københavns fattigvæsens hovedkasse i overensstemmelse med forskrifterne af Danske Lov 6-214 og forordning af 27. september 1799 om trykkefrihedens grænser $\int 12$ sidste membrum. Desuden betaler indstæunte til det offentlige rettens gebyr, skriversalarium samt omkostninger til stemplet papir. Endelig betaler han til citanten 25 rigsdaler sølv, som salær til dennes sagfører. Det idømte udredes inden 15 dage fra dommens lovlige forkyndelse. ${ }^{68}$

Grundtvig dømmes i overensstemmelse med forskrifterne i Danske Lov 6-21-4, som gælder den, der lastede kongen og hans regering eller som skamskændede øvrigheden og hæderlige folk. I æressager kan straffen varieres efter graden af sigtelsens grovhed. ${ }^{69}$ Grundtvig dømmes ligeledes i overensstemmelse med den $\mathrm{Kgl}$. forordning af 27. september 1799 om trykkefrihedens grænser $₫ 12$ sidste membrum; denne paragraf omhandler strafudmåling for æresskænderi mod private, og det hedder: "Ere Ordene ikke nogens Ære og Lempe for nær, og dog kendes af Dommeren at være utilbørlige, da maa de med Pengestraf forsones, eftersom de ere grove til."Videre står der, at straffen skal udmåles under hensyntagen til, at det anses for mere æreskrænkende, hvis angrebet er blevet fremsat på tryk, end hvis det er fremført mundtligt. Bøderammen angives til mellem 50 og 1000 rigsdaler sølv. ${ }^{70}$ Disse paragraffer taget $\mathrm{i}$ betragtning er dommen særdeles mild; dels anser retten øjensynlig kun Grundtvigs udtalelser for utilbørlige og ikke decideret ærekrænkende, og dels bliver Grundtvig idømt en meget lav bøde, på trods af hans udtalelser er fremført på tryk. Grundtvig blev, som det fremgår af dommen, dømt til at betale 100 rigsdaler sølv til Københavns fattigvæsens hovedkasse, 25 rigsdaler til Clausens sagfører Sporon samt rettens gebyr og sagsomkostninger til det offentlige. Treschow fik anonymt tilsendt 200 rigsdaler med besked om at betale bøden og omkostningerne for Grundtvig og selv beholde 
det resterende beløb, så økonomisk blev selve retssagen ikke nogen belastning for Grundtvig, men det, der blev en belastning for Grundtvig, og som ikke umiddelbart fremgår af dommen, er, at han blev underlagt livsvarig censur. I forordning af 27. september 1799 om trykkefrihedens grænser hedder det nemlig i $\S 20$, at enhver, der dømmes i overensstemmelse med denne forordning, i fremtiden, dvs. på livstid, ikke må lade noget skrift trykke, førend det har været forevist stedets politimester, og af ham forsynet med påskriften "Maa Trykkes " ${ }^{71}$ Ifølge Gerda Cortsen, tidligere dommerfuldmægtig i Lyngby, der har været mig behjæelpelig med dels juridisk ekspertise og dels håndskrifttydning (retsprotokollerne), bør enhver dom kunne stå alene, hvilket vil sige, at bilag af enhver art skulle være overflødige til forståelsen af sagen i alle dens detailler. Dette kan man ikke ligefrem sige om denne dom, som Gerda Cortsen da også karakteriserer som værende juridisk teknisk dårlig. Som eksempel herpå kan nævnes, at det faktisk ikke fremgår af dommen, hvilke udtryk det er, der kendes for "døde og magtesløse at være". For at finde frem til disse udtalelser skal vi helt tilbage til Sporons første retsindlæg af d. 10/10-1825. Ligeledes forekommer det mig meget besynderligt, at retten på den ene side afviser at undersøge sagens realitet: Om Clausen er en falsk lærer, hvilket vil sige om hans lære, som den fremgår af hans bog, er i strid med den danske statskirkeforfatning og dens symbolske bøger, når retten på den anden side indlader sig på at udtale, at Clausens lære $\mathrm{i}$ det væsentlige synes at stemme overens med bispernes hyrdebrev af 1817, der dårligt kan optræde som en autoritet på linie med de symbolske bøger og kirkeforfatningen. Retten vil altså ikke afgøre om Clausens lære er falsk, men den vil godt udtale, at noget af Clausens lære ifølge hyrdebrevet af 1817 er sandt. Morsomt er det også at konstatere, at der i dommen ikke forekommer nogen drøftelse af, hvorvidt Grundtvigs udtryk er utilbørlige eller for den sags skyld en begrundelse for at de skulle være det; det konstateres blot gang på gang. Grundtvigs udtalelser kan nemlig kun kaldes utilbørlige, såfremt de ikke har hold i virkeligheden, for Danske Lov hjemler ret til at kalde en der lyver en løgner, en der stjæler en tyv og så fremdeles. Disse uoverensstemmelser sammenholdt med, at Grundtvig faktisk får en ualmindelig mild straf, gør det svært ikke at få den tanke, at 
kancelliet og domstolen allerede inden det første retsmøde havde truffet beslutning om sagens udfald, men det vil selvfølgelig aldrig kunne bevises - herom kan kun gisnes. ${ }^{72}$

\section{Afslutning}

Det er givet, at Grundtvig var både nedtrykt og utilfreds med den behandling såvel kancelliet som domstolen havde givet sagen. Clausen var derimod i starten ganske godt tilfreds, idet han mente, at dommen dels rensede ham personligt og dels statuerede den videnskabelige frihed samt frikendte ham for misbrug af samme. ${ }^{1}$ Clausens tilfredshed svinder imidlertid, efterhånden som det går op for ham, at Lindberg agter at fortsætte angrebene på ham og hans lære. Grundtvig appellerede ikke dommen, selv om han ifølge et utrykt manuskript skrevet umiddelbart efter domsafsigelsen øjensynlig har overvejet denne mulighed. ${ }^{2}$ Lindberg og hans meningsfaller var skuffede, idet de mente det ville have tvunget staten til at tage stilling til symbolforpligtelsen og den konfessionelle kamp. Men dette var ikke længere væsentligt for Grundtvig. Det han ønskede at kæmpe for, var den hellige almindelige kirke og dens dåbspagt; blot denne ikke blev krænket, så kunne Grundtvig godt tolerere afvigelser fra det Luthersk konfessionelle. ${ }^{3}$ Men Lindberg ønskede ikke at afslutte sagen, og i dec. 1826 udkom hans skrift "Den Kgl. Landsover- samt Hofog Statsrets Kjendelse og Dom i Sagen Dr., Prof. H.N. Clausen contra Pastor N.F.S. Grundtvig, bedømt af J.C. Lindberg", i hvilket kan kritiserede såvel kendelsen som dommen og udbyggede alle Grundtvigs argumenter. Mere opsigt vakte det imidlertid, at han i forordet bragte et brev fra N.M. Spandet, der var assessor ved den kgl. landsover- samt hof- og stadsret. Spandet skriver her, at han betragter det forhold, som Grundtvig blev dømt for, som ulasteligt. Münter angav straks skriftet til kancelliet, og begge blev tilkendt en kongelig irettesættelse. ${ }^{4}$

"Gienmælet " og dets budskab var næsten druknet i skandalelyst, personlige og politiske opgør, og blev fra først af betragtet som et led i den konfessionelle kamp. Grundtvigs kirkelige anskuelse, hvis man overhovedet kan tale om en sådan i 1825-26, blev ikke forstået rigtigt hverken af Grundtvigs forbundsfæller 
eller af hans fjender. Grundtvigs intention med "Gienmælet " var at fremkalde en debat om hvad der var sand kristendom, om dennes forhold til statskirkeforfatningen, om rationalisternes og dermed Clausens lære set $\mathrm{i}$ forhold til statskirkeforfatningen, og endelig en debat om præsteedens indhold og udstrækning. Men der var faktisk ingen, der ønskede at diskutere disse ting med Grundtvig. Dette og trusselen om livsvarig censur tvinger Grundtvig til ikke længere at kæmpe for den sande kristendom, men til at kæmpe imod censuren. Præsteedens alvorlighed hævder han gennem hele sagen.

Når Grundtvigs forbundsfæller i starten tog den "mageløse opdagelse" til sig, var det, fordi den umiddelbart befriede menigheden fra de ofte rationalistiske lærdes eksegetiske pavedømme. Bibelen var ikke længere "Guds Ord", og den egentlige autoritet, Apostolicum, der var kendt af alle, var et brugbart våben i den kirkelige konfessionelle og sociale kamp. ${ }^{5}$ Men efterhånden blev det klart, at Grundtvig drog andre kirkelige og kirkepolitiske konsekvenser af "Gienmælet og "opdagelsen" end de øvrige "Gammeldagstroende». For Grundtvig var "Opdagelsen " andet og mere end blot et middel til at skille farrene fra bukkene. Alt i alt må man konkludere, at den "mageløse opdagelse " og "Gienmælet « i første omgang ikke fik den store indflydelse på kirkekampen.

Først i begyndelsen af 1827 ytrer Grundtvig sig offentligt om dommen i artiklen "Om Religions-Frihed ", hvis første og andet afsnit bringes i januar- og februarnumrene af "Theologisk Maanedsskrift «. Tredie og sidste afsnit blev undertrykt af censuren, hvilket givet skyldes, at denne sidste del udarter til en uforbeholden kritik af sagsbehandlingen og dommen, som kaldes uretfærdig og tilskrives Ørsteds utidige votum i sagen. Artiklen munder ud $\mathrm{i}$ en ligefrem bøn til kongen om at eftergive censuren. Selv om denne del undertrykkes af censuren, sender Grundtvig alligevel en anmodning til kongen om at ophæve censuren i april 1827, i hvilken han anfører sin økonomiske situation og tilintetgjorte borgerlige ære som grund til, at kongen skulle forbarme sig over ham. ${ }^{6}$ Kancelliet fraråder imidlertid kongen at eftergive Grundtvig censuren, fordi stormen omkring sagen endnu ikke har lagt sig, og fordi det meget vel kunne tolkes således, at kongen tog Grundtvigs parti, såfremt han op- 
hævede censuren. Ørsted er morsomt nok i opposition til resten af kancelliet i denne sag; han havde jo selv et lignende problem efter den famøse artikel om kirkeforfatningen. Kongen fulgte kancelliets henstilling, og Grundtvigs anmodning blev afslået ved en kongelig resolution d. 2/5-1827.

Til slut skal det blot bemærkes, at Grundtvigs censur bliver ophævet i december 1837, ikke - som man kunne formode alene ved kongens nåde, men ved at en lovændring gjorde det muligt at underlægge folk censur i en begrænset årrække.

\section{Anvendt litteratur}

De i margen anførte forkortelser anvendes i noterne.

J.O.A. J. Oskar Andersen: "Om Kirkens Gienmæle 1825. "Dansk Kirkeliv medens Tiderne skifter 1925.

K.B. Kai Baagø: "Magister Jacob Christian Lindberg, " Kbh. 1958.

G.C.\&S.G. Georg Christensen og Stener Grundtvig: "Breve til og fra N.F.S. Grundtvig “ II, Kbh. 1926.

H.N.C.a. H.N. Clausen: "Om Injuriantens og den Injuriederes Stilling i Danmark, et Ord til nærmere Overvejelse. " Kbh. 1832.

H.N.C.b. H.N. Clausen: "Optegnelser om mit Levneds og min Tids Historie." Kbh. 1877.

H.N.C.c. H.N. Clausen: "Mindre Arbejder: Kirkelige Forhold og Anliggender." Kbh. 1885.

H.J.H.G. H.J.H. Glædemark: "N.F.S. Grundtvigs nedlæggelse af Præsteembedet $i$ 1826. " Kirkehistoriske Samlinger, 6. række, bind 3. Kbh. 1939-41.

L.G. Leif Grane: "Ørsted og Kirkekampen i 1820'rne. "Fra "Anders Sandøe Ørsted, 1778-1978 foredrag $\mathrm{i}$ anledning af 200 året for Anders Sandøe Ørsteds fødsel, udgivet af Ditlev Tamm. “ Kbh. 1980.

U.S. $\quad$ N.F.S. Grundtvig: "Udvalgte Skrifter ved Holger Begtrup. " Kbh. 190409.

N.F.S.G. N.F.S. Grundtvig: "Vigtige Spørgsmaal til Danmarks Lovkyndige. " Kbh. 1826.

G.\&I. Grundtvig \& Ingemann. "Brevveksling" udgivet af Svend Grundtvig. Kbh. 1882.

G.\&M. Grundtvig \& Molbech: "Christian Molbech og N.F.S. Grundtvig; en brevveksling, " samlet af Ch. K.S. Molbech og udgivet af L. Schrøder. Kbh. 1888. 
S.J.\&H.H. Steen Johansen \& Henning Høirup: "Grundtvigs Erindringer og Erindringer om Grundtvig."

H.J. Harald Jørgensen: "Trykkefrihedsspørgsmålet i Danmark 1799-1848. “ Kbh. 1944.

J.L. Jørgen Larsen: "H.N. Clausen, hans Liv og Gerninger" I. Kbh. 1945.

J.C.L.a. J.C. Lindberg: "Bemærkninger i anledning af Kirkens Gienmæle. « Kbh. 1825.

J.C.L.b. J.C. Lindberg: "Den Kongelige Landsover- samt Hof- og Stadsrets Kjendelse og Dom i Sagen Dr. Prof. Theol. H.N. Clausen contra Pastor N.F.S. Grundtvig, bedømt af J.C. Lindberg. " Kbh. 1826.

P.G.L. P.G. Lindhardt: "Vakkelser og Kirkelige Retninger. " $\AA$ Århus 1978.

J.P.M. J.P. Mynster: "Meddelelser om mit Levned. « Kbh. 1884.

F.R. F. Rønning: "N.F.S. Grundtvig. " Kbh. 1907.

K.T. K. Thaning: "Den "mageløse opdagelse «s tilblivelse. " Grundtvig-Studier 1981.

V.P. Den Kongelige Lansdover- samt Hof- og Stadsrets voteringsprotokol. Justitskontoret 1. instans 7. (1826, 26/9-1827, 17/7). (Landsarkivet).

D.P. Den Kongelige Landsover- samt Hof- og Stadsrets domprotokol. Justitskontoret XXIX A. 1. instans. (1825, 23/8-1827, 16/10). (Landsarkivet).

\section{Noter til indledningen:}

1. Jvf. U.S. IV p. 397.

2. Jvf. K.T.

\section{Noter til Injuriesagen:}

1. Jvf. H.J.H.G. p. 270.

2. Jvf. H.J.H.G. p. 264, F.R. III,I, p. 115 \& J.L. p. 154.

3. Jvf. J.P.M. p. 228.

4. Jvf. H.J.H.G. p. 265 \& F.R. III,I, p. 117-118.

5. Jvf. F.R. III,I, p. 116-117, H.N.C.b. p. 118 \& J.L. p. 156.

6. Jvf. G.C.\&S.G. p. 106.

7. Jvf. J.L. p. 156-157, F.R. III,I, p. 125 \& H.J.H.G. p. 127 note 5.

8. Jvf. H.N.C.b. p. 129.

9. Jvf. H.N.C.b. p. 111-112.

10. Prinsensgade 312 er det nuværende Prinsessegade 52.

11. Jvf. F.R. III,I, p. 128.

12. Jvf. H.J.H.G. p. 265-266.

13. Jvf. F.R. III,I, p. 129.

14. Jvf. H.J.H.G. p. 265.

15. Jvf. H.J.H.G. p. 267.

16. Jvf. F.R. III,I. p. 129. 
17. P.E. Sporon var Grundtvigs tidligere elev fra det Schouboeske Institut.

18. Jvf. F.R. III,I, p. 127-129 \& H.J. p. 346.

19. Jvf. U.S. IV. p. 430.

20. Jvf. H.J.H.G. p. 272-276.

21. Jvf. G\&I. p. 73.

22. Jvf. G\&I. p. 73

23. Jvf. H.J.H.G. p. 274-275, F.R. III,I, p. 121-125 \& J.L. p. 157-160.

24. Jvf. J.L. p. 158-161.

25. Jvf. G\&I. p. $79-80$ \& H.J.H.G. p. 222-224.

26. Jvf. J.C.L.b. p. 15-18.

27. Jvf. F.R. III,I. p. 129 \& H.J.H.G. p. 280-281.

28. Jvf. H.J.H.G. p. 286-287 \& F.R. III,I. p. 139-140.

29. Jvf. H.J.H.G. p. 287 \& F.R. III,I. p. 140.

30. Jvf. G.C.\&S.G. p. $110-111$ \& F.R. III,I, p. $140 \&$ H.J.H.G. p. 287.

31. Jvf. H.J.H.G. p. 287-288, F.R. III,I, p. 140-141 \& U.S. IV. p. 734.

32. Jvf. F.R. III,I. p. $141 \&$ H.J.H.G. p. 282.

33. Jvf. H.J.H.G. p. 265-266 \& p. 268-297.

34. Jvf. H.J.H.G. p. 265-266.

35. Jvf. H.J.H.G. p. $217-219$ \& p. 291-292 \& G.C.\&S.G. p. 112-113.

36. Jvf. G.C.\&S.G. p. 115.

37. Jvf. G\&I. p. $80 \&$ H.J.H.G. p. 222-224.

38. Jvf. G\&I, p. 80 \& H.J.H.G. p. 224.

39. H.J.H.G. p. 219-221 \& p. 295.

40. Jvf. S.J.\&H.H. p. 113. Enkeprovstinde Blicher døde d. 28/4-1826.

41. Jvf. H.J.H.G. p. 295 \& F.R., III,I. p. 143.

42. Jvf. H.J.H.G. p. 219 note 1 \& F.R. III,I. p. 143-144.

43. Jvf. F.R., III,I, p. 143-144.

44. Jvf. F.R. III,I p. 145-146 \& H.J.H.G. p. 225 \& p. 233-234.

45. Jvf. G.C.\&S.G. p. 114-130, F.R. III,I, p. 146-147 \& H.J.H.G. p. 222, 241-247 \& p. 254 \& G\&I. p. 78-81.

46. Jvf. H.N.C.b. p. 112-113 \& F.R. III,I, p. 148.

47. Jvf. H.N.C.b. p. 113-114 \& F.R. III,I, p. 148-149.

48. Jvf. H.J.H.G. p. 228-229 \& F.R. III,I, p. 149-150.

49. Jvf. F.R. III,I, p. 150.

50. Jvf. F.R. III,I, p. $150-151$ \& H.N.C.c. p. $720-756$.

51. Jvf. H.N.C.c. p. $718-720$.

52. Jvf. H.N.C.c. p. 720.

53. Jvf. H.N.C.c. p. 721-756.

54. Jvf. H.N.C.c. p. 755-756.

55. Jvf. H.J.H.G. p. 230-231.

56. Jvf. F.R. III,I. p. 152 \& H.J.H.G. p. 230-231.

57. Jvf. L.G. p. 135.

58. Jvf. H.N.C.c. p. 745 ff.

59. Jvf. N.F.S.G. p. 3-4.

60. Jvf. Jvf. U.S.V. p. 144-148.

61. Jvf. J.L. p. 165.

62. Jvf. L.G. p. 134. 
63. Jvf. L.G. p. 133-136, J.L. p. 164-166, K.B. p. 95 \& H.N.C.b. p. 129-130.

64. Jvf. G.C.\&S.G. p. 130-131.

65. Jvf. V.P. p. 87-93 \& D.P. p. 372-378, de fem dommere var: Niels L. Schiønning, Christian Rothe, Daniel Blechinberg, Jacob Stendrup og Christian H. Carstens.

66. Jvf. Sporons første retsindlæg.

67. Hyrdebrevet af 1817.

68. Jvf. V.P. p. $87-93$ \& D.P. p. 372-378, F.R. III,I, p. 158-159, J.L. p. 170 \& J.C.L.b. p. 46-52.

69. Jvf. H.J. p. 15.

70. Jvf. H.J. p. 29-33 \& F.R. III,I, p. 159.

71. Jvf. H.J. p. 29-33 \& F.R. III,I. p. 159.

72. Jvf. J.C.L.b. p. 52-83, F.R. III,I. p. 160 \& G. Cortsen personlig meddelelse.

\section{Noter til afslutningen:}

1. Jvf. J.L. p. $170-171$.

2. Jvf. K.B. p. 98-99.

3. Jvf. P.G.L. p. 41.

4. Jvf. J.C.L.b. p. $137 \&$ U.S.V. p. $45 \&$ p. 95-153.

5. Jvf. P.G.L. p. $41 \&$ p. 47.

6. Jvf. G.C.\&S.G. p. $135-137$ \& U.S.V. p. 45 \& p. 95-153. 